\title{
Erratum to: Grazers and vitamins shape chain formation in a bloom-forming dinoflagellate, Cochlodinium polykrikoides
}

\author{
Xiaodong Jiang $\cdot$ Darcy J. Lonsdale
}

Christopher J. Gobler

Published online: 5 August 2010

(C) Springer-Verlag 2010

\section{Erratum to: Oecologia}

DOI 10.1007/s00442-010-1695-0

A funding source was not included in the "Acknowledgments" section of the original publication of this article. It should read as:

This work was also supported by NSF Biological Oceanography award 0623432 to C.J.G.

The online version of the original article can be found under doi: 10.1007/s00442-010-1695-0.

X. Jiang $(\varangle) \cdot$ D. J. Lonsdale · C. J. Gobler School of Marine and Atmospheric Sciences, Stony Brook University, Stony Brook,

NY 11794-5000, USA

e-mail: xiajiang@ic.sunysb.edu 